\title{
Going beyond cognitive approach to behavioral stream in economic sciences: Behavioristic and evolutionary perspectives
}

\section{Dominika Korzeniowska ${ }^{1}$ iD , Łukasz Sułkowski}

\begin{abstract}
The paper is a proposal of the triangulation of a theory basis for the behavioral stream in economic sciences that currently mostly uses a cognitive approach, by adopting a behavioristic and evolutionary perspective into that scope of reflection. A narrative literature review of scientific databases by means of Internet search engines based on the combinations of relevant keywords was used. The final selection included 37 articles and 21 monographs subjected to further analysis. The analysis showed that by adopting other perspectives than just a cognitive one into behavioral economics research can enrich theoretical and empirical foundations, provide new research tools, and enable discoveries on human economic behaviors. Evolutionary concepts also seem to gain in importance nowadays, especially in terms of neuroscientific methods used to investigate how the human brain functions. The combination of all three approaches seems quite promising and worth further development, as it may lead to not only uncovering the mechanisms underlying economic behaviors but also may help people to make better decisions. Thanks to the combination of the three approaches (paradigms) pictured together (which has not previously been present in the literature on the subject), the paper aims to inspire behavioral economic researchers to search for the theoretical basis of their scientific quest going beyond the cognitive canon, to facilitate embedding their studies in a proper paradigm or finding the relevant concept/theory, and also recognizing niche or complementary research areas. Therefore, the article adds to a discussion on the theoretical foundations of the stream and the process of shaping its scientific identity.
\end{abstract}

Keywords: behavioral economics, behavioral finance, behavioral accounting, behaviorism, evolutionism

\footnotetext{
1 Dominika Korzeniowska, Ph.D., University of Social Science, Sienkiewicza 9, 90-113 Lodz, Poland, e-mail: dkorzeniowska@san.edu.pl (ORCID ID: 0000-0001-5806-9332), coressponding author.

2 Łukasz Sułkowski, Prof., University of Social Science, Sienkiewicza 9, 90-113 Lodz, Poland, e-mail: Isulkowski@san.edu.pl (ORCID ID: 0000-0002-1248-2743).
}

Received 20 November 2018; Revised 31 May 2019, 9 October 2019, 14 October 2019; Accepted 4 November 2019. This is an open access article under the CC BY license (https://creativecommons.org/licenses/by/4.0/legalcode). 


\section{INTRODUCTION}

Over the last few years, more and more has been written in the literature on the science of interdisciplinarity, its causes, manifestations, forms, and types (Dudziak, 2013). Leaving aside the discussion on the need and significance of - on the one hand, fragmentation, and on the other hand, the integration of scientific knowledge - the development of an interdisciplinary approach entails some essential problems connected with the theoretical background of the newly created streams. The tendency to structure descriptions of reality considering the perspectives of multiple disciplines has also been present in the economic sciences. Casting doubt on their main paradigm of homo oeconomicus has led to an increased interest, mostly in the concepts and methodology of psychology and sociology. One manifestation of these divergent searches is the dynamically developing behavioral stream, which consists of behavioral economics, behavioral finance, and behavioral accounting. Additionally, some of the neurosciences emerged as part of this tendency (neuroeconomics, neurofinance, neuroaccounting, neuromarketing), which apply some of the research methods used in biology, medicine and chemistry, such as magnetic resonance, electroencephalography and positron emission tomography (c.f., Artienwicz, 2015).

Scientists operating within the behavioral stream of economic sciences seem to focus mostly on its empirical aspect, meaning extensive research activity with the dissemination of their findings. The literature on the subject has not yet seen any broader discussion on, for example, macro-theories that would provide an epistemological basis, and would, therefore, contribute to the distinctness and identity of these subdisciplines. The existing reflection is mostly founded on certain assumptions drawn from cognitive psychology, which deal with research into cognitive structures and processes, and into the organization and functioning of the human mind (Maruszewski, 1996; Materska \& Tyszka, 1997; Nęcka, Orzechowski, \& Szymura, 2006). Cognitive psychology, however, treats these structures, processes, and the ways the human mind works as existing elements. Moreover, cognitive psychologists assume that architecture of the brain has "a general purpose" and is devoid of content. In other words, the same information processing mechanisms are used in resolving various problems, no matter what their nature is. These general mechanisms allow for logical thinking, learning, recognizing similarities, creating concepts, and memorizing. But investigation e.g. why they developed in a particular way or how to shape external conditions in order to obtain the desired behavior, still remains open. A cognitive approach seems to be an insufficient basis for finding a comprehensive answer to such doubts. The main research question of the paper then is 
$R Q$ : What other paradigms the behavioral stream in economic sciences can draw from, to enhance its epistemic value?

In particular, what theories and concepts within those paradigms may be of assistance in discovering the causes underlying economic behaviors. Literature studies indicate that two paradigms look especially promising in that respect i.e. evolutionary and behavioristic. According to evolutionary psychologists (in contrast to a cognitive approach), the human mind consists of a large number of specialized (not general) mechanisms, each of which is used to solve a different adaptive problem (Winterhalder, 2007). While behaviorism holds the position that the only thing that can be controlled and can be studied is behavior itself, not mental processes. Perhaps then, extending the cognitive perspective with such issues would provide the inspiration to develop new research and to make valuable discoveries. Behaviorism and the evolutionary theory, particularly in their psychological aspects, could become the basis for finding explanations and roots of the existing patterns of human economic behavior.

The aim of this article is, thus, taking the floor in the discourse on the paradigms and theories underlying the behavioral stream in economic sciences by proposing an enlargement of their theory basis, going beyond the prevailing cognitive canon. Two emergent theories for that scope of reflection are, as mentioned above, behaviorism and evolutionism. The article will first describe the areas of interest in the subdisciplines of this stream, considering their currently dominant paradigm. It will then discuss changes in the research perspective relating to the use of behaviorism and evolutionism as a new theoretical and empirical basis.

\section{RESEARCH METHOD}

The methodology of the paper is based on a narrative literature review which adopts a less formal approach than systematic reviews (Jahan, Naveed, Zeshan, \& Tahir, 2016). The main disadvantage of such a method is its subjectivity resulting from a less explicit methodology to identify, select, and evaluate results. However, the paper's character is introductory, so the approach adopted herein to select the relevant bibliography was rather qualitative. The primary motive was to identify possible paradigms used by behavioral economic researchers and outline their specifics, not to verify e.g. which paradigm was the most frequently used. Nevertheless, a systematic review of the literature could become a valuable continuation of the issues raised in this article, as it would probably reveal other concepts or theories applicable 
to behavioral economic research. The review was conducted through Internet search engines. The following databases were explored: Business Source Complete, Academic Search Complete, Science Direct, SpringerLink, Web of Science, and Google Scholar.

The combinations of the following keywords and expressions were used: cognitive psychology, evolutionary psychology, behavioral psychology, behavioral economics, behavioral accounting, behavioral finance, behavioral aspects, behaviorism, behavioristic, evolutionary, evolutionism, neoevolutionism, neo-evolutionism, and neoevolutionary. Additional search criteria were applied: only full text records published in Polish or English as reviewed publications were included. In total, 1884 results were obtained. It turned out that EBSCO also returned many unrelated items (medical, technical, etc.). They were not further analyzed ( $527 \mathrm{left}$ ). The publication time span was limited to the period of the last 40 years to exclude the works that may already be outdated. Then, after removing duplicates, the search base was thus limited to 286 items. Next, the titles and abstracts of the selected publications were examined to verify the relevance of their content. Finally, the analysis was based on 37 articles and 21 monographs published in the years 1979-2019.

\section{NARRATIVE LITERATURE REVIEW}

\section{The behavioral stream in economic sciences}

It is assumed that the behavioral stream in economic sciences includes behavioral economics, finance, and accounting. All three subdisciplines aim to explain various economic (in general) behaviors. However, most findings and explanations are based on a cognitive approach. The following fragments briefly present the essence of these three subdisciplines, including their definitions as well as areas of their research interests. This should all be treated as the necessary basis for discussion on the possibility of using the behaviorist and evolutionary paradigms in further research, in this respect.

The term 'behavioral economics' was coined by K. Boulding in 1958, in which the author indicated the need to study certain human ideas or emotional and cognitive structures that have an impact on economic decisions (Angner \& Loewenstein, 2006). The idea of looking for findings that would explain economic phenomena based on the knowledge of a person's psycho-social functioning thus emerged. Cartwright (2001) describes it as the science of applying the conclusions of laboratory experiments, psychology, and other social sciences to economics. Polish authors, on the other hand, have narrowed down the designata of the object of behavioral economics, 
from the perspective of the scale of use of findings provided by the science of human behavior. They conclude that, instead, its attempts to build more realistic models of economic thinking and behavior are thanks to the use of the achievements of psychology, which equipped with proper, descriptive theories of decision-making, helps to explain human weaknesses, limitations or insufficient rationality (Brzeziński, Gorynia, \& Hockuba, 2008). Behavioral economics studies concentrate, among others, on entrepreneurship, consumers' behaviors, saving money, insuring oneself, paying taxes, risktaking, motivation to work, and money perception (Artienwicz, 2018).

Behavioral finance, treated by some researchers as a part of behavioral economics, focuses on the behavior of investors in the financial markets, using psychological aspects (Zielonka, 2003; Tyszka, 2003). Behavioral finance attempts to explain and increase understanding of the reasoning patterns of investors, including the emotional processes involved and the degree to which they influence the decision-making process. Essentially, behavioral finance attempts to explain the what, why, and how of finance and investing, from a human perspective (Ricciardi \& Simon, 2000).

The neoclassical theory of finance is based on the assumptions of rationality of the investors' behaviors and market effectiveness, which virtually permeate each other as there is no effective market if investors act irrationally. However, the reality of the stock market has painfully verified these assumptions on several occasions (Hersh, 2002). It turns out that participants of financial markets fall into all kinds of mental traps, with the most common being: overconfidence, illusions of control, over-optimism, confirmation bias, anchoring, the affect heuristic, the status quo effect, and the disposition effect (Zielonka, 2003). Besides cognitive biases, behavioral finance research also focuses on anomalies (deviations from market efficiency), investors' motivational tendencies, behavioral portfolio theory, deferred payments discounting, etc. (Zielonka, 2019).

"Behavioral accounting is an offspring from the union of accounting and behavioral science. It represents the application of the method and outlook of behavioral science to accounting problems" (Report of The Committee, 1974, p. 127). Its fundamental aim is to explain and predict human behavior in all possible aspects of accounting (Belkaoui, 1989). According to a different description of its area of interest, it is a dimension of accounting related to human behavior and its connection with planning, developing, and using an effective accounting system (Siegel \& Ramanauskas-Marconi, 1999). A similar approach is proposed by Cieciura (Cieciura, 2015, p. 36): "The subject of its research covers issues concerning the behavior of people involved in an accounting system." Belkaoui clarifies that "behavioral accounting emphasizes the relevance of accounting information to decision-making, 
as well as the individual and group behavior caused by the communication of this information", and that "its purpose is to influence action or behavior directly through the information content of the message conveyed and indirectly through the behavior of accountants" (Belkaoui, 1989, Preface). Thus, he also draws attention to such issues as group behavior, including the behavior of accountants.

Some of the ultimate goals of classical accounting are delivering a real and reliable image of the material and financial situation of a unit and providing economic information allowing the recipients of this information to formulate opinions and judgments and to make further decisions (Micherda, 2007). This very approach might be prone to behavioral distortions, as accounting is practiced by people, for people (Arnold \& Sutton, 1997). Thus, the way data provided in the form of all kinds of reports is presented can affect the choices made based on it. In contrast, the ability of the recipients of the accounting information to read and analyze it correctly and to make the right decision based on it might be limited by human intellectual potential (e.g., Sithole, 2016). Behavioral accounting research concerns such issues as managerial control, accounting information processing, accounting information system design, auditing process research, and organizational sociology (Birnberg \& Shields, 1989).

In the research subject of these three subdisciplines outlined above, one may conclude that 'behavioral' definitely means 'related to behavior.' However, this adjective is mostly understood by the cognitive paradigm. The carried-out research aims to explain human behavior from the perspective of the way people perceive economic, financial, and accounting situations, the way they interpret them, what they already know about them, and what their expectations of them are. Cognitive psychology forms both the theoretical and methodological basis for the research conducted within this stream. That is exceptionally well visible in the research design. The research mostly focuses on discovering and describing mechanisms leading to distortion of the rationality of thinking and decision-making processes - heuristics and other similar phenomena - as a result of which people choose shortcuts or give in to their emotions. However, to be able to isolate particular factors that disturb rational thinking, quite artificial research conditions have to be created. Cognitive researchers are "accused of" not paying too much attention to the stimuli employed in their experiments. They choose them rather according to their ease of use and the possibility of effortless manipulation in experimental conditions (Buss, 2001). That is why they prefer some abstract categories instead of real ones. They use it purposefully, as they want to get rid of all the content that the respondents could have had earlier contact with, and that could "contaminate" the final results. Their aim is to grasp 
"pure" causal inference. Those "precautions" are, however, only valid if the human mind is a "general-purpose" processor. What if cognitive mechanisms are specialized in processing information about specific problems, not "the general ones"? It seems that explaining why these mechanisms developed and why they developed the way they did, maybe difficult based only on a cognitive paradigm. Perhaps the behaviorist approach is a step towards getting to know more of the root causes of this state.

\section{What if 'behavioral' comes from behaviorism?}

If we assume that the adjective 'behavioral' comes from a trend in psychology and philosophy called behaviorism, then the phrase 'the behavioral stream in economic sciences' takes on a completely different meaning. To "decipher" this new meaning, one must first look at the main tenets of behaviorism (c.f., Staddon, 2016).

It is believed that creation of this trend was affected not only by Pavlov's experiments or Thorndike's discoveries but also by Darwin's theory of evolution. Behaviorism assumes that behavior is "mostly controlled by environmental factors such as imitating the behavior of others, reinforcement and conditioning" (Winstanley, 2008, p. 183). "When trying to understand behavior, behaviorism adopts (...) an experimental approach, suggesting that psychology should (...) focus on an objective study into observable behavior, and not thoughts or cognitive processes. Behaviorists believe that 'facts' cannot be reached by looking into human thoughts and minds as people may lie or be mistaken" (Winstanley, 2008, p. 27, as cited in Nowak, 2015). The "truth" can be revealed by studying only the things that can be observed, i.e. behavior and environmental stimuli that trigger this behavior. A significant part of this approach is behavior analysis, which seeks universal laws and regularities that describe relationships between environmental independent variables and behavior, which is a dependent variable. There are two types of environmental factors: a) events that have occurred so far in the environment being a consequence of a specific behavior (positive and negative reinforcements) and b) formerly and currently existing environmental conditions that are the background of activity and changes that appear in the environment under its influence (differential and extinction stimuli) (Bąbel \& Ostaszewski, 2008).

Reading between the lines of the above descriptions, one can also find the three basic assumptions of behaviorism. First of all, it assumes that human behavior results from the influence of the environment (environmentalism), which is manifested in the existence of rewards and punishments. Second, the patterns governing human behavior can be identified by performing experiments (experimentalism), and third, if one recognizes elements of the 
environment affecting behavior, then by changing these elements, one can change human behavior (optimism) (Nowak, 2015). The first two assumptions are particularly in accordance with the assumptions of Darwinian thought. The examples of research based on behavioristic theories/concepts (evoked in subsections' titles) will be presented in the following fragments.

\section{Conditioning}

Interestingly, despite the obvious dominance of the cognitive approach in these three subdisciplines, research in this field does include attempts to apply the behaviorist perspective. For example, mechanisms of the effect of money have been studied within behavioral economics based on a conditioning hypothesis. Pursuant to this approach, "money should be interpreted as the generalized conditional reinforcement connected with all kinds of consumer goods (such as food), acting as unconditioned reinforcers" (Zaleśkiewicz, 2011 , p. 193). Thus, people need money in order to obtain other things that they find attractive. Money is also a universal good, meaning that it allows for selection from an unlimited range of products, which additionally increases its value (Simmel, 1997, p. 182). Adopting such an approach, one can see - for example, in the development of incentive systems for employees and the rules and regulations of remuneration used to train/condition employees - that efficient performance of certain professional tasks results in the obtaining of specific financial reinforcers.

Another example is a practice called "token economy." According to the theory of operant conditioning, delayed gratification is far less effective than immediate reward. However, most immediate reinforcers cannot be used in a quick and reproducible manner. In order to overcome this, the idea emerged to substitute the primary reward with a secondary reward in the form of a token that can be then exchanged for the real "carrot." This method has proved to be very successful in shaping the behavior of schizophrenics and children with social disorders (Zaleśkiewicz, 2011).

Conditioning, and particularly instrumental conditioning, has also been used by 'behavioral accountants' in their studies into functional fixation (or, in fact, data fixation) (Korzeniowska, 2018). In its original psychological version, functional fixation is a lack of the ability to use a given object (thing) in a nonstandard way, contrary to its intended purpose. With regard to accounting, it is more often a data fixation, meaning "the tendency of users of information provided by the accounting system to understand accounting categories (values) in a uniform way, even in cases when methods employed for the calculation of these categories (values) are fully disclosed" (Bloom, Elgers, \& Murray, 1984). An example of the conditioning mechanism in accounting is as follows: Sterling 
(Sterling, 1970) found that the "production" of reports is accompanied by "impressive ceremony," engaging both managers and accountants. Thus, the recipients of these reports get the impression that they need to respond to them because they are the results of a very complicated ritual involving many people. Thus, accountants respond to financial data because they are taught (conditioned) to respond to them, not because the data has any significant informational content. Even if it does, there is the question of whether accountants respond appropriately (Belkaoui, 1989). Perhaps they only respond in a previously acquired manner, regardless of the methods employed to obtain the results presented. In this case, it would require them to change their behavior, i.e. to pay additional psychological 'costs.' It is worth bearing in mind that accountants, in the course of their professional education, learn the rules, procedures and methods of accounting, and of financial reports drawn up using these rules and procedures. They also learn methods of ratio analysis and cash flow, in the case of which accounting data is used to assess a company's effectiveness and perspectives. Thus, they are 'indoctrinated' during their education concerning ways of determining the correctness and usefulness of information from accounting systems. Then such 'indoctrination' is reinforced continuously by each report they receive in their everyday work.

\section{Matching law}

The matching law formulated by Herrnstein (1970) may also be of assistance in explaining human economic behaviors. Matching law is an attempt to quantify Thorndike's law of effect (Thorndike, 1970), which says that the reaction force is directly proportional to the pleasure that comes after it. The more reinforcing power the behavior's consequence has, the stronger the reaction force will be. Herrnstein claims that if there are two simultaneously available competing reactions, the relative frequency of response to one of them will be equal to the relative frequency of reinforcements obtained from it (Herrnstein, 1970). People invest more of their time and resources in something they like doing. Daniels (1999) (after Bąbel \& Ostaszewski, 2008) enumerates several consequences of matching law relating to the employees' performance at work. For instance, if the job provides weak reinforcements even a small external reinforcement will distract people from their work, if some changes are introduced (new structure, responsibilities, procedures, software, etc.) managers have to remember to also implement proper reinforcements to induce employees to use them, as the old reinforcements are still active and may affect the effectiveness of the new solutions. Interestingly, as evidenced by numerous research, matching law "works" not only with human beings (Baum, 1975) but also with animals like monkeys, rats, 
pigeons, hamsters, cows, or hens (e.g., Anderson, Velkey, \& Woolverton, 2002). The vast majority of research on matching law studied various characteristics of reinforcements such as their: frequency, probability, deferment, or size. However, in real life, we encounter numerous reinforcements that differ both in terms of quantity and quality. Another question then arises; that is whether people's involvement in certain behavior depends on the availability of reinforcements' substitutes in our environment. Such a question makes another interesting research area where behaviorism (matching law) meets behavioral economic sciences (phenomenon of substitution).

Scholars representing a behaviorist approach noticed the analogy between economics and behavior analysis. Reinforcements are the equivalent of goods in economics, and the prices of these goods represent the number of reactions needed to receive them. If the number of reactions to get a specific reinforcement increases, and there is another reinforcement (substitute) available. The consumption of a substitute reinforcement will increase; the more, the better the substitute of the "original" reinforcement is. There were many studies on animals' behaviors in terms of food choices based on these assumptions, e.g. Green and Freed (2000), but similar patterns can be observed in humans as well. Foxal (1999) analyzed the frequency of purchases of various coffee brands. Taking into consideration the FMCG industry, there are a lot of brands available for a certain type of goods. If we want to buy e.g. mineral water and the prices of different products are similar we should choose the cheapest one (assuming no impact of marketing activities) as all of them will satisfy the same need. However, Foxall concluded that coffee brands were not treated as substitutes. Consumers did not pick one type of coffee, but their preferences were changing. If those products were not the same in terms of quality, the consumers' behavior was not against matching law. Although the results of Foxall's research are not unambiguous, it can become an inspiration for behavioral economists to further studies on the law of effect or other "behavioristic" phenomena.

\section{Nudging}

There is another concept inscribed in the behaviorist paradigm that cannot be ignored while considering its influence on economic behaviors. This concept was popularized in 2008 by Thaler and Sunstein although it has its source in much earlier works (Wilk, 1999). It is about libertarian paternalism known under its more attractive name - "nudging." "A nudge is any aspect of the choice architecture that alters people's behavior in a predictable way without forbidding any options or significantly changing their economic incentives. A mere nudge, the intervention must be easy and cheap to 
avoid. Nudges are not mandates. Putting fruit at eye level counts as a nudge. Banning junk food does not" (Thaler \& Sunstein, 2008, p. 6). In other words, nudging is about influence made by rulers or creators of decision-making situations on individuals in such a way that they make decisions that are optimal for them. The idea is not, however, to influence the individuals' decisions through orders, prohibitions, or manipulations. Creators or rulers only have to shape the decision-making situation in such a way as to guide decision-makers to the optimal variants for them and limit irrational actions (resulting e.g. from cognitive biases). Comprehensive elaboration on the nudging phenomenon is far beyond the capacity of this paper, but even from its sole definition cited above it is clear that this is an evident example of a gentle form of behavior shaping.

If the three subdisciplines making up behavioral economic sciences are perceived from the behavioristic perspective, they will deal with an experimental study into human responses to different economic, financial, and accounting stimuli. Thus, it would not matter what kind of distortion occurred when making a decision in a given situation, but what kind of behavior was evoked by, for example, imposing a tax, stock prices going up, or reading a financial report.

\section{What does evolutionism offer the behavioral stream in economic sciences?}

The evolutionary metaphor has been broadly used in economics, for example, in the analyses by Joseph Schumpeter, Thorstein Veblen, Kurt Dopfer, and Ulrich Witt. Evolutionary assumptions of selection, changeability, and reproduction have been applied to economic organizations and the economic market, which has led to the use of some biological terms that were related to population, ecology, and balance. Contemporary scholars who use evolutionary analogies in economics are usually aware of cognitive limitations brought about by the transfer of biological terms to such a discourse (Dopfer, 2001; Witt, 2008).

The evolutionary approach is a relatively new one in behavioral economic sciences and is rarely used cognitively. Among several different applications of evolutionism in economic sciences, three approaches can be distinguished. First, it appears as a kind of paradigm or meta-theory describing human nature and social behaviors, on which the entire economy, management, and finances are founded. In the literature on the subject, we can also find authors questioning the usefulness of evolutionism (mostly in its new form, neoevolutionism) in economics, and even in social sciences in general (Poirot, 2007). Second, it is used as a source of variables explaining various economic behaviors. For example, it may be a study of the relationship between 
financial behavior and gender or age, in which the concept of "Pleistocene mind" will be used. Third, evolutionism (neoevolutionism) may be a source of research methods that expand the traditional range of methods used in economic sciences so far.

Key research questions are related to the search for a decision-making model in conditions of uncertainty, the analyses of perceptive and cognitive illusions, and interpretation of man's economic behavior in the categories of evolutionary cognitive models. The methodology of this trend is primarily based on social experiments but uses statistical, demographical and historical analyses as well (Camerer, Loewenstein, \& Rabin, 2001). Thanks to the use of brain examination techniques, it is nowadays possible to study, among other things, the neuronal bases of decision-making. Hence, within behavioral economic sciences, there also exists a related and developing branch of neuroeconomics, neurofinance, and neuroraccounting. Neuroeconomics is understood as "the study of the biological microfoundations of economic cognition and economic behavior. Biological microfoundations are neurochemical mechanisms and pathways, like brain regions, neurons, genes, and neurotransmitters. Economic cognition includes memory, preferences, emotions, mental representations, expectations, anticipation, learning, perception, information processing, inference, simulation, valuation, and the subjective experience of reward. In general, neuroeconomic research seeks to identify and test biologically microfounded models that link cognitive building blocks to economic behavior" (Camerer, Cohen, Fehr, Glimcher, \& Laibson, 2015, p. 153). This definition, however, if slightly adjusted to financial and accounting conditions, will also "fit" to neurofinance and neuroraccounting. It seems then that the evolutionary approach legitimates inclusion into behavioral economic sciences also their "neuroversions." Such inclusion, based only on cognitive paradigm, would not be fully justified.

The trends development confirms the openness of behavioral economic sciences, as scientific subdisciplines, to new theoretical and empirical inspirations. The idea of bounded rationality was introduced to the economic discourse by Simon (1955). However, relations between behavioral economics and evolutionism are very modern and involve the search for evolutionary sources of economic behavior. Bounded rationality examines, for example, evolutionary conditions for risk aversion (Kahneman \& Tversky, 1979) and the question of trust and reciprocity (Fehr \& Schmidt, 1999; Falk, Fehr, \& Zehnder, 2006; Fehr, 2009; Fehr \& List, 2004). Studies on the evolutionary aversion to risky decisions or unconscious motives for purchasing consumer goods, related to our species' past, form problems that can be solved by means of scientific methods deriving from various disciplines, which might be one of the reasons for their innovative character. According to G. Loewenstein, however, 
evolutionary conditions cannot be the only variable factor that is taken into account while making informed economic decisions (Camerer et al., 2001).

It seems that evolutionism (neoevolutionism) can be of benefit to researchers and practitioners of behavioral economic sciences as it proposes a coherent paradigm explaining human economic behaviors, providing detailed behavioral theories related to decision-making, and proposing an innovative research methodology as well as pragmatic guidelines. An evolutionary approach adopts some assumptions that are different from those applied by cognitive psychologists and that integrate a cognitive approach with other human-related sciences (Tooby \& Cosmides, 1992). The main assumption is that the human mind consists of many information-processing mechanisms that evolved in the course of evolution and are embedded in the human nervous system. Those mechanisms are adaptations resulting from the laws of natural selection functioning in the environment of our ancestors and are functionally specialized, that is certain mechanisms are responsible for resolving certain adaptive problems. To be able to be functionally specialized; however, these mechanisms must be imbued with content (in contrast to a cognitive canon where the content is neglected) (Buss, 2001).

\section{Ecological rationality}

Due to the above assumptions, the evolutionary approach tends to question, at least to some extent, the conclusions from research conducted within the cognitive canon. The main doubt is whether human cognition is, in fact, full of errors and biases stemming directly from the imperfections of our information processing skills. Having in mind that our ancestors were able to solve quite numerous and complicated problems connected with their survival and reproduction, the answer is no longer as simple as it initially seemed. Another argument for the fact that the human mind cannot be boiled down only to the category of an imperfect machine with limited data processing abilities is that even artificial intelligence systems (although they are guided by the principles of iron logic and use formal decision-making procedures) sometimes encounter difficulties in solving tasks which the living person copes well with. Tooby and Cosmides (1992) thus propose an approach that they called "ecological rationality." Their logic is that the human race in the course of evolution observed various kinds of patterns (named "ecological structure"); for example, rain falls on thunder, angry shouts precede violence, moving closer to a snake may result in a bite. Ecological rationality is made of mechanisms that use an ecological structure to resolve problems (Buss, 2001). In other words, our cognitive abilities are closely related to the patterns that occurred in the environment of our ancestors. Tooby and Cosmides explain 
that cognitive biases are due to a discrepancy between the problem and the mechanism set up to solve it. Our brain has been "evolutionally shaped" so that we have a fear of snakes or spiders as those animals may be dangerous for our lives. But we are not afraid of electrical sockets, because they appeared in our environment relatively recently, and that is too short for our internal anxiety mechanism to develop. Evolutionary psychologists claim that problem solving strategies have evolved in response to a specific problem, and in solving that particular problem, they are doing very well. However, they do not cope with new or artificially created problems, i.e. those that did not exist in their evolutionary environment (Buss, 2001).

According to Tooby and Cosmides (1992), formal logic rules that people should follow while making their choices are not suitable for solving real adaptive problems. From the perspective of evolution and natural selection, the real measure of success is survival and reproduction, not "objective truth" or logical consistency. There is no general rational rule being able to solve problems regardless of their specifics. Problem solving contains three factors: the problem itself, available tools, and circumstances. None of those three is general. For example, there are some plants that are poisonous for human beings but life-giving for other creatures. Logic cannot help to resolve the adaptive task of whether to eat a certain plant or avoid it in general. It can be solved by a mechanism tuned to a specific problem that was evolutionarily shaped by observation of the consequences of harmful substances consumption. The real environment of our ancestors was a kind of laboratory where various, differently "forged" cognitive mechanisms were tested, and only those that worked endured.

\section{Probability comprehension}

"Cognitive school" focuses on showing biases in estimating the probabilities of certain events occurrence. "Evolutionary school" indicates that in Pleistocene numerical procedures to assess the probability did not exist. Our ancestors simply had no idea what the probability was. That is why the suggestion is to rather speak about frequency (how many times lately I was in the forest and I found mushrooms), not a probability (what is the probability of finding mushrooms in the forest). The frequency hypothesis was tested by Cosmides and Tooby (1996) in the so-called medical diagnosis problem. Although the research task had a medical nature, it can be easily adapted to economic situations e.g. bankruptcy predictions based on discriminant models. The original task was (probability "frame"): 
"If a test to detect a disease whose prevalence is $1 / 1000$ has a false positive rate of $5 \%$, what is the chance that a person found to have a positive result actually has the disease, assuming that you know nothing about the person's symptoms or signs? $\% . "$

Only $18 \%$ of subjects who belonged to the group of faculty, staff and fourth-year students at Harvard Medical School answered " $2 \%$ ", which is correct. But when the problem was formulated as follows (frequency "frame"):

"1 out of every 1000 Americans has disease X. A test has been developed to detect when a person has disease X. Every time the test is given to a person who has the disease, the test comes out positive (i.e., the "true positive" rate is $100 \%)$. But sometimes the test also comes out positive when it is given to a person who is completely healthy. Specifically, out of every 1000 people who are perfectly healthy, 50 of them test positive for the disease (i.e., the "false positive" rate is $5 \%$ ). Imagine that we have assembled a random sample of 1000 Americans. They were selected by a lottery. Those who conducted the lottery had no information about the health status of any of these people. Given the information above: on average, how many people who test positive for the disease will actually have the disease? _ out of __" $76 \%$ of respondents answered correctly.

However, scholars had another idea to improve the results. So far, the task was presented in words. Knowing that writing has been known to people for only 5000 years, there was a supposition that graphical representation should result in even better outcomes. Hence researchers adjusted their test and presented a sample of 100 people in the form of squares (1 square $=1$ person) and asked the subjects to depict the information in a visual form (to circle the square that represents a person actually having the disease, to fill in the square indicating the person that has tested positive for the disease). Then respondents were asked to estimate how many people who test positive for the disease will have the disease (_ out of __). It turned out that as many as $92 \%$ of the respondents gave correct answers (Cosmides \& Tooby, 1996). The scholars concluded that people did not neglect information if they were presented in a way similar to that familiar to our ancestors. These findings seem to question, to some extent, the concept of the disability of human problem-solving mechanisms proclaimed by cognitivism. Maybe then, the suitable formulation of a problem using graphic forms or frequency representations instead of probability measures in financial reports would reduce the number of the traps that decision-makers "fall into" and would transform into better economic choices. 


\section{Somatic marker hypothesis}

The impact of evolutionism, although not mentioned "by name," on behavioral economic research can be especially visible in experiments making use of various neuroimaging techniques. Let then an experiment based on the lowa Gambling Task (IGT) and using galvanic skin response (GSR) be another illustration of the "evolutionary thought" in behavioral economic sciences. It has been discovered that people with frontal lobe lesion exhibit defects in decision-making, consisting primarily of their inability to choose options beneficial in the long term (Bechara, 2002). The research aimed to test the "somatic marker hypothesis" which belongs to a group of "risk as emotion" hypothesis that interpret decision-making as a process developed as a result of the biological evolution of the human mind. Briefly speaking, human choices are highly adaptive, so decision variants that trigger fear will be rejected, while those generating positive emotions will be accepted. It means that our "evolutionary brain" will decide "for us," and our consciousness will just try to find satisfactory justification for our choice. In IGT, participants were presented with four decks of cards on a computer screen. On each deck, there were cards that bring a prize or a fine. The goal of the game was to win as much money as possible. Decks differed from one another by balancing reward cards and penalty cards. Two decks were "bad decks," and the other two were "good decks". Then, consistent selection of bad decks turned out to be unfavorable in the long term. People with frontal lobe lesion chose more cards from the "bad decks" regardless of whether they did it for the first time or after an hour, a month, or a half year. It was because they were missing the physiological warning response (measured by GSR), which was activated by a healthy brain. For healthy subjects, a warning signal (stronger galvanic skin response) appeared before the card was pulled out of the "bad deck" even before they realized the real nature of the task. Hence, in the course of evolution, the human brain was shaped so as to even unconsciously help us to choose more favorable strategies.

\section{CONCLUSION}

Behavioral economic sciences constitute a relatively new area of knowledge that does not yet have well-grounded theoretical foundations. However, bearing in mind their dynamic development, there is an increasing need for theoretical discussion on paradigms or concepts that may contribute to the process of shaping the scientific identity of this stream. The outcomes of the above considerations are as follows: 
- so far, the behavioral stream in economic sciences has been mostly based on the cognitive paradigm, which dominated the research perspective in this area. The cognitive paradigm serves well if its main aim is to denude human limitations in information processing capacities, logical thinking, memory, etc.

- a great problem related to the application of the cognitive paradigm in research into behavioral economic sciences is that it does not offer a satisfactory basis for searching for methods of preventing violations of rationality in economic decisions (apart from the supposition that by making the decision-makers aware of the existence of decision traps, their impact may be slightly mitigated);

- explaining economic behaviors can be based on various paradigms i.a. behavioristic and evolutionary. It does not mean, however, that a cognitive approach should be discredited in favor of the theory of evolution or behaviorism, or lead to a split between academics, thus creating competing schools: the cognitive, behaviorist, and evolutionary. Some mechanisms were created in the course of evolution. However, in the case of economics, finance and accounting, there are different abstract categories that we can learn to apply in the course of socialization;

- evolutionism, especially evolutionary psychology, provides explanations of the genesis of specific automatic response patterns that have developed in the course of evolution that may help to create a new image of the human economic mind, economic society, or culture;

- evolutionary adaptation mechanisms show quite a different picture of the human cognitive potential. It turns out that there might be no single (general) intelligence but many variants, no single thinking ability, but many specific mental skills dependent on factors influencing their formation, no general learning, memorizing, imitation, or term creation ability, but many specialized cognitive mechanisms;

- thanks to the application of the behavioristic approach, perhaps it would be possible to find ways of eliminating the effects of mind traps by formulating recommendations on how to structure decisionrelated tasks (environment modeling), so as to ensure (nudge) responses (behaviors) that are proper (free of errors) in a given situation. Another advantage could be creating some guidance on how to teach or train people dealing with various economic problems to make them develop (learn) appropriate response mechanisms relevant to specific decision-making situations;

- to have a comprehensive view on particular economic behavior, triangulation of paradigms i.e. a theory basis, as well as research methods, is highly advisable. It could help to change the way of thinking about these areas of knowledge and would be a spur to structuring research in a different way, using different research 
methods and taking a different perspective of the results, which could translate into valuable new discoveries in the functioning of the human mind under different economic situations;

- the integration of methods specific to different paradigms could lead to research programs realized by representatives of various scientific disciplines, including economists, psychologists, radiologists, or doctors. Advancements in brain imaging techniques, especially noticeable in recent years, have significantly expanded the possibilities of studying economic behaviors. Discovering brain areas that respond to specific economic problems can help in finding answers to theoretical dilemmas that have not yet been resolved by other methods. Thanks to "neuroexperiments" it is also possible to analyze some automatic response patterns or emotions, which are often not available to the consciousness, and therefore "not suitable" for research utilizing e.g. "pure" laboratory experiments (mostly based on the cognitive paradigm).

The paper's intention is not only to support scientists in placing their scientific ventures in a proper theoretical framework but also to encourage them to search for other theories and concepts, not only within cognitive, behavioristic, or evolutionary paradigms. To that end, further discussion and research development, e.g. in the form of a systematic literature review which could probably lead to discovering other approaches applicable to behavioral economic sciences or testing new ones in terms of their epistemic potential, seems highly desirable.

\section{References}

Anderson, K.G., Velkey, A.J., \& Woolverton, W.L. (2002). The generalized matching law as a predictor of choice between cocaine and food in rhesus monkeys. Psychopharmacology 163(3-4), 319-26.

Angner, E., \& Loewenstein, G. (2006). Behavioral economics. In P. Thagard \& J. Woods (Eds.), Handbook of the Philosophy of Science. Amsterdam: Elsevier. Retrieved from http://www.cmu.edu/dietrich/sds/docs/ loewenstein/BehavioralEconomics.pdf

Arnold, V., \& Sutton, B. (Eds.) (1997). Behavioral Accounting Research. Foundations and Frontiers. Sarasota, FL: American Accounting Association.

Artienwicz, N. (2015). Neurorachunkowość jako potencjalny, ale trudny kierunek rozwoju rachunkowości. Zeszyty Teoretyczne Rachunkowości, 82(138), 9-17. http://doi.org/10.5604/16414381.1155803

Artienwicz, N. (2018). Rachunkowość Behawioralna. Warszawa: CeDeWu. Baum, W.M. (1975). Time allocation in human vigilance. Journal of the Experimental Analysis of Behavior, 23(1), 45-53. 
Bąbel P., \& Ostaszewski P. (Eds.). (2008). Współczesna Psychologia Behawioralna. Wybrane Zagadnienia. Kraków: Wydawnictwo Uniwersytetu Jagiellońskiego.

Bechara, A., \& Damasio, H. (2002). Decision-making and addiction (part I): Impaired activation of somatic states in substance dependent individuals when pondering decisions with negative future consequences. Neuropsychologia, 40(10), 1675-89.

Belkaoui, A. (1989). Behavioral Accounting. The Research and Practical Issues. New York, London: Quorum Books.

Birnberg, J.G., \& Shields, J.F. (1989). Three decades of behavioral accounting research: A search for order. Behavioral Research in Accounting, 1, 23-74.

Bloom, R., Elgers, P., \& Murray, D. (1984). Functional fixation in product pricing: A comparison of individuals and groups. Accounting, Organizations and Society, 9(1), 1-11. http://doi.org/10.1016/0361-3682(84)90026-6

Brzeziński, M., Gorynia, M., \& Hockuba, Z. (2008). Ekonomia a inne nauki społeczne na początku XXI. In Między imperializmem a korporacją. Ekonomista, 2, 217-218.

Buss, D.M. (2001). Psychologia Ewolucyjna. Jak Wytłumaczyć Społeczne Zachowania Człowieka? Najnowsze Koncepcje. Gdańsk: Gdańskie Wydawnictwo Psychologiczne.

Camerer, C.F., Loewenstein, G., \& Rabin, M. (Eds.). (2001). Advances in Behavioral Economics. Priceton, NJ: Princeton University Press.

Camerer, C., Cohen, J., Fehr, E., Glimcher, P., \& Laibson, D. (2015). Neuroeconomics. In Handbook of Experimental Economics. Retrieved from https://scholar.harvard.edu/files/laibson/files/camerer_cohen_ fehr_glimcher_laibson_2014.pdf

Cartwright, E. (2011). Behavioral Economics. London, New York: Routledge (Kindle Edition, loc. 116).

Cieciura, M. (2015). Behawioralne aspekty rachunkowości we współczesnej gospodarce-zarys problemu. PraceNaukowe UniwersytetuEkonomicznego we Wrocławiu, 388, 32-40. http://doi.org/10.15611/pn.2015.388.03

Cosmides, L., \& Tooby, J. (1996). Are humans good intuitive statisticians after all? Rethinking some conclusions from the literature on judgment under uncertainty. Cognition, 58, 1-73.

Dopfer, K. (2001). Evolutionary economics. Program and scope, Boston: Kluwer Academic Publishers.

Dudziak, S. (2013). Ekonomia behawioralna - interdyscyplinarne podejście do zachowań ekonomicznych. Studia i Prace Wydziału Nauk Ekonomicznych i Zarzqdzania, 2(32), 23-35.

Falk, A., Fehr, E., \& Zehnder, Ch. (2006). Fairness perceptions and reservation wages - The behavioral effects of minimum wage laws. The Quarterly Journal of Economics, 121(4), 1347-1381. http://doi.org/10.1093/qje/121.4.1347

Fehr, E. (2009). On the economics and biology of trust. Journal of the European Economic Association, 7(2-3), 235-266. http://doi.org/10.1162/ JEEA.2009.7.2-3.235 
Fehr, E., \& List, J.A. (2004). The hidden costs and returns of incentives-trust and trustworthiness among CEOs. Journal of the European Economic Association, 2(5), 743-771. http://doi.org/10.1162/1542476042782297

Fehr, E., \& Schmidt, K.M. (1999). A theory of fairness, competition, and cooperation. Quarterly Journal of Economics, 114(3), 817-868.

Foxal, G.R. (1999). The substitutability of brands. Managerial and Decision Economics, 20(5), 241-257.

Green, L., \& Fisher, E.B. (2000). Economic substitutability: Some implications for health behavior. In W.K. Bickel \& R.E. Vuchinich (Eds), Reframing Health Behavior Change with Behavioral Economics, (pp. 115-144). New Jersey: Lawrence Erlbaum Associates Publishers.

Herrnstein, R.J. (1970). On the law of effect. Journal of The Experimental Analysis of Behavior, 13(2), 243-266.

Jahan, N., Naveed S., Zeshan, M., \& Tahir, M. (2016). How to conduct a systematic review: A narrative literature review. Cureus, 8(11): e864. http://doi.org/10.7759/cureus.864

Hersh, S. (2002). Beyond Greed and Fear: Understanding Behavioral Finance and the Psychology of Investing, New York: Oxford University Press.

Kahneman, D., \& Tversky, A. (1979). Prospect theory: An analysis of decision under risk. Econometrica, 47(2), 263-291.

Korzeniowska, D. (2018). Zjawisko fiksacji funkcjonalnej w rachunkowości. Entrepreneurship and Management, XIX, 10(1). 209-224.

Maruszewski, T. (1996). Psychologia Poznawcza. Warszawa: Polskie Towarzystwo Semiotyczne.

Materska, M., \& Tyszka, T. (Eds). (1997). Psychologia i Poznanie. Warszawa: Wydawnictwo Naukowe PWN.

Micherda, B. (2007). Podstawy Rachunkowości. Aspekty Teoretyczne i Praktyczne. Warszawa: Wydawnictwo Naukowe PWN.

Nęcka, E., Orzechowski, J., \& Szymura, B. (2006). Psychologia Poznawcza, Warszawa: Wydawnictwo Naukowe PWN.

Nowak, M. (2015). Pomiędzy rachunkowością a psami Pawłowa, czyli krytyka pojęcia "rachunkowość behawioralna". Prace Naukowe Uniwersytetu Ekonomicznego we Wrocławiu, 389, 287-296. http://doi.org/10.15611/ pn.2015.389.26

Poirot, C. (2007). How can institutional economics be an evolutionary science? Journal of Economic Issues, 41(1), 155-179.

Report of the Committee on the Relationship of Behavioral Science and Accounting. (1974). The Accounting Review, 49(4), 127-139.

Ricciardi, V., \& Simon, K.H. (2000). What is behavioral finance?. Business, Education \& Technology Journal, 2(2), 1-9.

Sen, A. (1973). Behaviour and the concept of preference. Economica New Series, 40(159), 241-259.

Siegel, G., \& Ramanauskas-Marconi, H. (1999). Behavioral Accounting. Mason, OH: Thomson South-Western.

Simmel, G. (1997). Filozofia Pieniq̨dza. Poznań: Wydawnictwo Fundacji Humaniora. 
Simon, H. (1955). A behavioral model of rational choice. The Quarterly Journal of Economics, 69(1), 99-118. http://doi.org/10.2307/1884852

Sithole, S.T.M. (2016). The effects of presentation formats on understanding financial accounting: An experimental study. Australasian Accounting, Business and Finance Journal, 10(2), 76-92. http://doi.org/10.14453/aabfj.v10i2.5

Staddon, J. (2016). Theoretical behaviorism, economic theory, and choice. History of Political Economy, 48(1), 316-331.

Sterling, R. (1970). On theory construction and verification. The Accounting Review, 45(3), 444-457.

Thaler, R., \& Sunstein C. (2008). Nudge. New York: Penguin Books.

Thorndike, E.L. (1970). Animal Intelligence. Experimental Studies. New Brunswick, London: Transaction Publishers.

Tooby, J., \& Cosmides, L. (1992a). Psychological foundations of culture. In J. Barklow, J. Cosmides, \& J. Tooby (Eds), The Adapted Mind (pp. 19-136). New York: Oxford University Press.

Tooby, J. \& Cosmides, L. (1992b). Ecological rationality and the multimodular mind. Center for Evolutionary Psychology. Technical Report \#92-1. Santa Barbara, CA: University of California.

Tooby, J., \& Cosmides, L. (1996). Are humans good intuitive statisticians after all? Rethinking some conclusions from the literature on judgment under uncertainty. Cognition, 58, 1-73

Tyszka, T. (2003). Psychologia Ekonomiczna. Gdańsk: Gdańskie Wydawnictwo Psychologiczne.

Wilk, J. (1999). Mind, nature and the emerging science of change: An introduction to metamorphology. In G. Cornelis, S. Smets, \& J. Van Bendegem (Eds.), Einstein Meets Magritte: An Interdisciplinary Reflection and Science, Nature, Art, Human Action and Society (pp. 71-87). Netherlands: Springer.

Winstanley, J. (2008). Klucz do Psychologii. Najważniejsze teorie, pojęcia, postaci. Warszawa: Wydawnictwo Naukowe PWN.

Winterhalder, B. (2007). Risk and decision-making. In L. Barrett \& R. I. M. Dunbar (Eds.), Oxford Handbook of Evolutionary Psychology (pp. 433446). New York: Oxford University Press. http://doi.org/10.1093/ oxfordhb/9780198568308.013.0029

Witt, U. (2008). Evolutionary economics. In The New Palgrave Dictionary of Economics (pp. 67-68). London: Palgrave.

Zaleśkiewicz, T. (2011). Psychologia Ekonomiczna. Warszawa: Wydawnictwo Naukowe PWN.

Zielonka, P. (2019). Giełda i Psychologia. Behawioralne Aspekty Inwestowania na Rynku Papierów Wartościowych. Warszawa: CeDeWu.

Zielonka, P. (2003). Czym są finanse behawioralne, czyli krótkie wprowadzenie do psychologii rynków finansowych. Materiały i Studia NBP, 158, 40-43. 


\begin{abstract}
Abstrakt
Artykuł stanowi propozycję włq̨czenia w podbudowę teoretycznq behawioralnego nurtu w naukach ekonomicznych, bazujqcego dotychczas przede wszystkim na podejściu poznawczym, również perspektyw behawioralnej oraz ewolucyjnej. Wykorzystano narracyjny przegląd literatury obecnej w zasobach Internetu. Piśmiennictwa poszukiwano przede wszystkim w elektronicznych bazach publikacji naukowych w oparciu o hasła odzwierciedlajqce tematykę artykułu. Ostateczny wybór obejmował 37 artykułów i 21 monografii, które poddano dalszej analizie. Analiza zgromadzonej literatury wykazała, że nurt behawioralny w naukach ekonomicznych, dzięki przyjęciu innych perspektyw niż tylko poznawcza, może istotnie wzbogacić swoje podstawy teoretyczne i empiryczne, w tym narzędzia badawcze, i stymulować nowe odkrycia dotyczqce ludzkich zachowań w sytuacjach ekonomicznych. Podejmowane sq już pewne próby badawcze oparte na podejściu behawiorystycznym, na przykład dotyczqce kwestii wpływu mechanizmu warunkowania na decyzje czy wykorzystaniu tzw. szturchania (nudging) w indukowaniu bardziej racjonalnych wyborów. Wydaje się także, iż obecnie na znaczeniu zyskujq coraz bardziej koncepcje ewolucyjne, co w szczególności przejawia się w rosnqcej popularności metod neuronauki stosowanych do badania funkcjonowania ludzkiego mózgu w trakcie podejmowania decyzji ekonomicznych. Kombinacja trzech omawianych tu podejść wydaje się dość obiecujq̨ca, nie tylko z uwagi na fakt, że umożliwia głębsze poznanie mechanizmów leżq̨cych u podstaw zachowań ekonomicznych, ale także może pomóc stworzyć narzędzia pozwalajqce ludziom podejmować lepsze decyzje. Zestawienie $w$ niniejszym artykule trzech podejść (paradygmatów), co dotychczas nie było praktykowane $w$ literaturze przedmiotu, może a) stanowić inspirację dla badaczy zajmujqcych się ekonomiq behawioralnq (czy też dyscyplinami pokrewnymi) do poszukiwania innych, niż te funkcjonujqce $w$ kanonie poznawczym, teoretycznych podstaw swych badań, b) ułatwić osadzenie tych badań we właściwym paradygmacie, w tym odnalezienie odpowiedniej koncepcji, teorii czy modelu, a także c) utorować rozpoznanie niszowych lub uzupełniajqcych się obszarów badawczych. Z powyższych względów artykuł ten stanowi uzupełnienie dyskusji na temat teoretycznych podstaw behawioralnego nurtu w naukach ekonomicznych i stanowi wkład w proces kształtowania się jego tożsamości naukowej.
\end{abstract}

Słowa kluczowe: ekonomia behawioralna, finanse behawioralne, rachunkowość behawioralna, behawioryzm, ewolucjonizm

\title{
Biographical notes
}

Dominika Korzeniowska is an assistant professor at the Department of Finance and Accounting at the University of Social Sciences in Lodz and is a CIMA (Chartered Institute of Management Accountants) qualified professional. Her scientific interests focus on the "human" side of economics, finance, and accounting, i.e. their behavioral "versions." She also works as a manager in one of the BPO centers in Lodz. 
Łukasz Sułkowski is a professor of economic sciences, specializing in management sciences. He is currently employed at the Institute of Public Affairs of the Jagiellonian University and Director of Clark University Branch Campus at University of Social Sciences in Poland. He is also the President of PCG Polska. He is Head of the Chair of Management of Higher Education Institutions at the Jagiellonian University, professor of Clark University, and University of Social Sciences. Since 2008, he has been the editor-in-chief of the Journal of Intercultural Management "(DE Gruyter). From 2004-2011, he was the editor-in-chief of "Organizacja i Kierowanie," a quarterly of the Committee of Organization and Management of the Polish Academy of Sciences "Organization and Management." An author or co-author of more than 300 publications, including 14 monographs published by such publishing houses as Springer, Lexington, Palgrave, Emerald, Lang, PWN, and PWE. He has been the project manager or coordinator of $16 \mathrm{EU}$ research grants (e.g., 6th Framework Programme, EQUAL), National Science Centre, Ministry of Science and Higher Education and State Committee for Scientific Research. He currently manages the "UNIFUT" project of the University of the Future and Organizational improvement of the University of the Future "("Dialogue," Ministry of Science and Higher Education). He is a member of 4 international research associations (AAM, EURAM, IFERA, and PGV). Since 2014, he has been a member of the Committee for Culture and Media Management of the Polish Academy of Arts and Sciences (PAU), Committee for Culture and Media Management (PAU). He is the Chairman of the cyclical conferences "Family Business: Managing Family Companies" (7 editions), "Intercultural Management Congress" (11 editions). He has been the promoter of 14 Ph.D. dissertations at five universities and a reviewer in several dozen professorial, habilitation, and doctoral proceedings.

\section{Conflicts of interest}

The authors declare no conflict of interest.

\section{Citation (APA Style)}

Korzeniowska, D., \& Sułkowski, Ł. (2020). Going beyond cognitive approach to behavioural stream in economic sciences: Behavioristic and evolutionary perspectives. Journal of Entrepreneurship, Management and Innovation, 16(2), 13-35. https://doi.org/10.7341/20201621 